\title{
Changes in Polyribosomes and Poly(A)-Containing Polyribosomal RNA in the Uterus of the Ovariectomized Rat in Response to Oestradiol-17 $\beta$ Treatment
}

\author{
Petrus J. PRETORIUS and Carolus J. REINECKE \\ Department of Biochemistry, Potchefstroom University for Christian Higher Education, 2520 Potchefstroom, \\ Republic of South Africa
}

(Received 12 November 1979)

\begin{abstract}
Polyribosome formation and the characteristics of polyribosomal poly(A)-containing RNA from uteri of ovariectomized rats responding to a single dose of oestradiol-17 $\beta$ was investigated. The mean proportion of polyribosomes in the atrophic uterus was $65 \%$. In response to $10 \mu \mathrm{g}$ of oestradiol $-17 \beta / 100 \mathrm{~g}$ body mass, the amount of polyribosomes increased to $88 \% 24 \mathrm{~h}$ after stimulation. Thereafter the proportion of polyribosomes decreased to a value of $48 \%$ at $72 \mathrm{~h}$. The pattern of amino acid incorporation in oocytes from Xenopus laevis injected with these polyribosomes was similar to the changes in polyribosome formation and degradation. The polyribosomal poly(A)-containing RNA from the controls consisted of a heterogeneous population of RNA with sedimentation values between $5 \mathrm{~S}$ and $25 \mathrm{~S}$. The hormone stimulation resulted in an increase in both the amount and the size (13S to $35 \mathrm{~S})$ of the RNA.
\end{abstract}

It is well documented that the RNA metabolism in the uterus of the immature or ovariectomized adult rat is altered by the administration of oestradiol-17 $\beta$ (Katzenellenbogen \& Gorski, 1975; Catelli \& Baulieu, 1976). One of the main features of this response is the early induction of heterogeneous highmolecular-weight RNA molecules, followed by the synthesis of rRNA (Aziz \& Knowler, 1978; Luck, 1979). Both the rate of amino acid incorporation in vitro and the cytoplasmic concentration in vivo of the polyribosomes are subsequently increased by $100 \%$ at $12 \mathrm{~h}$ after treatment with a single dose of oestradiol-17 $\beta$ (Teng \& Hamilton, 1967). Although the total number of polyribosomes per uterus increases with time after oestradiol-17 $\beta$ treatment, it has furthermore been reported that the sucrosegradient profiles are indistinguishable (Teng \& Hamilton, 1967; Eilon \& Gorski, 1972), suggesting that an overall change in the size of polyribosomes or in the relative abundances of polymeric and monomeric ribosomes did not occur during the periods of hormone action examined. By contrast, it has recently been shown that oestradiol-17 $\beta$ treatment of the immature rat does result in the aggregation of monoribosomes into polyribosomes in the uterus (J. T. Knowler, personal communication). This is furthermore in accordance with Abbreviations used: poly(A)+ RNA, poly(A)-containing RNA; SDS, sodium dodecyl sulphate. electron-microscopic analysis of the effect of oestradiol-17 $\beta$ on the ultrastructural morphology of uterine tissue of the immature rat (Bo et al., 1968). The results in the present paper indicate that oestradiol-17 $\beta$ does also, in contrast with the previous reports, increase protein synthesis in the uterus of the ovariectomized rat, with a concomitant conversion of monoribosomes into polyribosomes. This observation implies that we could obtain polyribosomes of a high structural integrity in response to oestradiol-17 $\beta$, and opened the possibility of a study on structural characteristics of the poly(A) ${ }^{+}$RNA associated with the polyribosomes. Aspects of these results have been presented elsewhere (Pretorius \& Reinecke, 1979).

\section{Materials and Methods}

\section{Chemicals}

All the chemicals used were obtained from BDH or Merck. Oligo(dT)-cellulose type T2 was obtained from Collaborative Research (Waltham, MA, U.S.A.), the radioactive materials were from The Radiochemical Centre (Amersham, Bucks., U.K.), Eagle's minimal essential medium was from Gibco (Labretoria, Pretoria, South Africa) and Aquagel was from Chemlab (Pinegrove, South Africa). 


\section{Animals}

Female Sprague-Dawley rats weighing $150-180 \mathrm{~g}$ were ovariectomized 3 weeks before use. These rats received $10 \mu \mathrm{g}$ of oestradiol $-17 \beta / 100 \mathrm{~g}$ body wt. as a single intraperitoneal injection in $100 \mu \mathrm{l}$ of $0.9 \%$ $\mathrm{NaCl}$ containing 15-20\% (v/v) ethanol. Control animals received the carrier alone.

\section{Isolation of ribosomes}

The animals were killed by cervical dislocation and the uteri removed and immediately put on ice. They were stripped of fat and blood vessels, weighed and cut into small pieces. Homogenization (one or two uteri $/ \mathrm{ml}$ of buffer) was done with an UltraTurrax tissue disintegrator in homogenization buffer [50 mM-Tris/ $\mathrm{HCl}$, $\mathrm{pH} 7.6$, containing $250 \mathrm{~mm}-\mathrm{KCl}$, $15 \mathrm{~mm}-\mathrm{MgCl}_{2}, 0.1 \mathrm{~mm}$-EDTA, $10 \mathrm{~mm}-\beta$-mercaptoethanol and $250 \mathrm{~mm}$-sucrose (Suvatte \& Hagerman, 1970; Manchester, 1974)]. The homogenate was centrifuged at $8000 \mathrm{~g}$ for $10 \mathrm{~min}$ (rotor JA20 in Beckman model J-21B centrifuge) and the sediment re-extracted with the same volume of homogenization buffer. The pooled supernatants were treated for at least $20 \mathrm{~min}$ with sodium deoxycholate at a final concentration of $1 \%$ and were subsequently centrifuged at $14000 \mathrm{~g}$ for $10 \mathrm{~min}$ (rotor JA20). The supernatant was layered on top of $1.5 \mathrm{M}$-sucrose in homogenization buffer and centrifuged in rotor 42.1 in the Beckman model L2-65B ultracentrifuge for at least $90 \mathrm{~min}$ at $4^{\circ} \mathrm{C}$ and $40000 \mathrm{rev} . / \mathrm{min}$. The ribosomal pellet was rinsed once with ice-cold distilled water and any material adhering to the walls of the centrifuge tube was removed with tissue paper. For sedimentation analysis the ribosomes were suspended in suspension buffer $(20 \mathrm{mM}-\mathrm{Tris} / \mathrm{HCl}$, $\mathrm{pH} 7.6$, containing $80 \mathrm{mM}-\mathrm{KCl}, 5 \mathrm{mM}-\mathrm{MgCl}_{2}$ and $5 \mathrm{~mm}$ - $\beta$-mercaptoethanol). For the preparation of polyribosomal poly(A) ${ }^{+}$RNA the ribosomes were suspended in application buffer (see below). When not immediately used the suspended ribosomes were stored in liquid nitrogen.

\section{Sedimentation analysis of uterine ribosomes}

Sedimentation analysis was performed in linear $10-30 \%(\mathrm{w} / \mathrm{v})$ sucrose density gradients prepared in suspension buffer. Before sedimentation the ribosomal preparations were incubated for $5 \mathrm{~min}$ at $37^{\circ} \mathrm{C}$; $400 \mu \mathrm{g}$ of ribosomal material was used per gradient $\left(12 A_{260}\right.$ units $=1 \mathrm{mg}$ of ribosomes). The gradients were monitored at $260 \mathrm{~nm}$ and the relative sedimentation values of the uterine ribosomes were determined by comparison with rabbit reticulocyte ribosomes.

Translation of uterine ribosomes in Xenopus laevis oocytes

The ribosomes to be injected into oocytes ob- tained from mature female toads (Xenopus laevis) were suspended in injection buffer $(15 \mathrm{~mm}$-Tris $/ \mathrm{HCl}$, $\mathrm{pH} 7.6$, containing $88 \mathrm{~mm}-\mathrm{NaCl}$ and $10 \mathrm{~mm}-\mathrm{KCl}$ ) and injected into the oocytes as described by Gurdon et al. (1971). After injection the oocytes were incubated at $19^{\circ} \mathrm{C}$ for $15 \mathrm{~h}$ in modified Barth's medium (Gurdon et al., 1971) containing $50 \mu \mathrm{Ci}$ of $\mathrm{L}-\left[{ }^{14} \mathrm{C}\right]$ leucine $(331 \mathrm{mCi} / \mathrm{mmol}) / \mathrm{ml}$. Control injections of identical volumes of injection buffer were administered to oocytes to determine the endogenous activity of the oocytes. After incubation the incorporation of amino acids into total oocyte protein was determined as described by Chan et al. (1976).

\section{Preparation of polyribosomal poly $(A)^{+} R N A$}

Polyribosomal poly(A) ${ }^{+}$RNA was isolated by a procedure based on the techniques of Krystosek $e t$ al. (1975) and Busch (1976). The ribosomal preparation was suspended in application buffer $(10 \mathrm{~mm}-\mathrm{Tris} / \mathrm{HCl}, \mathrm{pH} 9.0, \quad 500 \mathrm{~mm}-\mathrm{NaCl})$ containing $0.5 \%$ SDS, incubated at $37^{\circ} \mathrm{C}$ for $5 \mathrm{~min}$ and applied to a $0.4 \mathrm{ml}$ oligo(dT)-cellulose column prepared in a $2.5 \mathrm{ml}$ disposable syringe. The column was washed thoroughly with application buffer containing $0.5 \%$ SDS, subsequently with the same buffer without SDS and then with $10 \mathrm{~mm}$-Tris $/ \mathrm{HCl}$, $\mathrm{pH}$ 7.6, containing $100 \mathrm{~mm}-\mathrm{KCl}$. The bound RNA was eluted from the column with distilled water. The RNA-containing eluate was adjusted to $10 \mathrm{mM}$ Tris/ $\mathrm{HCl}(\mathrm{pH} 7.6) / 500 \mathrm{mM}-\mathrm{NaCl}$, and heated at $70^{\circ} \mathrm{C}$ for $5 \mathrm{~min}$ to dissolve any aggregates between contaminating rRNA and poly(A) ${ }^{+}$RNA (Busch, 1976). The elution sequence was repeated and the fraction containing the bound RNA was made $200 \mathrm{mM}$ with respect to $\mathrm{NaCl}$ and the RNA precipitated overnight with $2 \mathrm{vol}$. of ethanol at $-20^{\circ} \mathrm{C}$. The efficiency of the column was regularly checked with commercial poly(A). Before use, all the buffers were treated with diethyl pyrocarbonate. The RNA yield was determined spectrophotometrically $\left(24 A_{260}\right.$ units $=1 \mathrm{mg}$ of RNA $)$.

\section{Labelling of poly $(A)^{+} R N A$}

Uteri (approx. $500 \mathrm{mg}$ of tissue) obtained from ovariectomized rats under different hormonal conditions were finely chopped and incubated at $37^{\circ} \mathrm{C}$ for $30 \mathrm{~min}$ in $2.5 \mathrm{ml}$ of Eagle's minimal essential medium containing $50 \mu \mathrm{Ci}$ of $\left[2-{ }^{3} \mathrm{H}\right]$ adenosine $(23 \mathrm{Ci} / \mathrm{mmol})$. After incubation, polyribosomes were isolated, from which poly $(\mathrm{A})^{+}$RNA was obtained as described above.

\section{Sedimentation analysis of $R N A$}

The sedimentation characteristics of the different fractions eluted from the the oligo(dT)-cellulose column were determined by centrifugation in linear 
$5-20 \%(\mathrm{w} / \mathrm{v})$ sucrose density gradients prepared in $10 \mathrm{~mm}$-Tris/ $\mathrm{HCl}, \mathrm{pH} 7.6$, containing $100 \mathrm{~mm}-\mathrm{NaCl}$ and $1 \mathrm{~mm}$-EDTA. The conditions of centrifugation are given in the legends to the Figures. The gradients were fractionated and the radioactivity of each fraction was determined in Aquagel.

\section{Results}

The structural integrity of the polyribosomes isolated from the uteri of control and oestrogen-treated animals was monitored by sucrose-density-gradient centrifugation. The sedimentation profiles obtained in a representative experiment are shown in Fig. 1. The ribosomes from uteri of control animals were present as $80 \mathrm{~S}$ monoribosomes, with decreasing amounts of oligomers (Fig. 1). The mean proportion of polyribosomes, obtained from ten independent experiments, was $65 \%$ (Fig. 2). In response to a single dose of oestradiol-17 $\beta$ the amount of polyribosomes increased, reaching a peak value of approx. $88 \%$ polyribosomes $24 \mathrm{~h}$ after stimulation. Therefore the proportion of the polyribosomes decreased to a value of $48 \%$ at $72 \mathrm{~h}$. This is even less than the proportion present before stimulation. The proportion of monoribosomes decreased from $30 \%$ in the control animals to $11 \%$ at $24 \mathrm{~h}$ after hormone treatment, after which the proportion again increased to $48 \%$ at $72 \mathrm{~h}$. (In all experiments approx. $5 \%$ of the material added to the gradient remained at the meniscus after centrifugation.)

We have noticed that a satisfactory resolution of the ribosomal distribution in sucrose gradients could only be obtained after a short incubation of the preparation at $37^{\circ} \mathrm{C}$ before sedimentation analysis. This was apparently due to a tendency of the robosomes, especially from control animals, to form dimers at $4^{\circ} \mathrm{C}$. This phenomenon of dimerization is known to be characteristic of rat ribosomes (Reader \& Stanners, 1967). The preincubation did not result in a significant change in the proportion of polyribosomes.

The lower ratio of polyribosomes in the control animals as compared with the hormone-treated animals (up to $24 \mathrm{~h}$ ) is not due to higher ribonuclease activity in the former. This is shown in Fig. 3. The polyribosomal profile of material isolated from uteri $6 \mathrm{~h}$ after hormone stimulation was virtually identical in the presence of a supernatant prepared from control uteri (a homogenate of unstimulated uteri was centrifuged in rotor 42.1 for $3 \mathrm{~h}$ at $40000 \mathrm{rev} . / \mathrm{min})$. This implicates very low or no

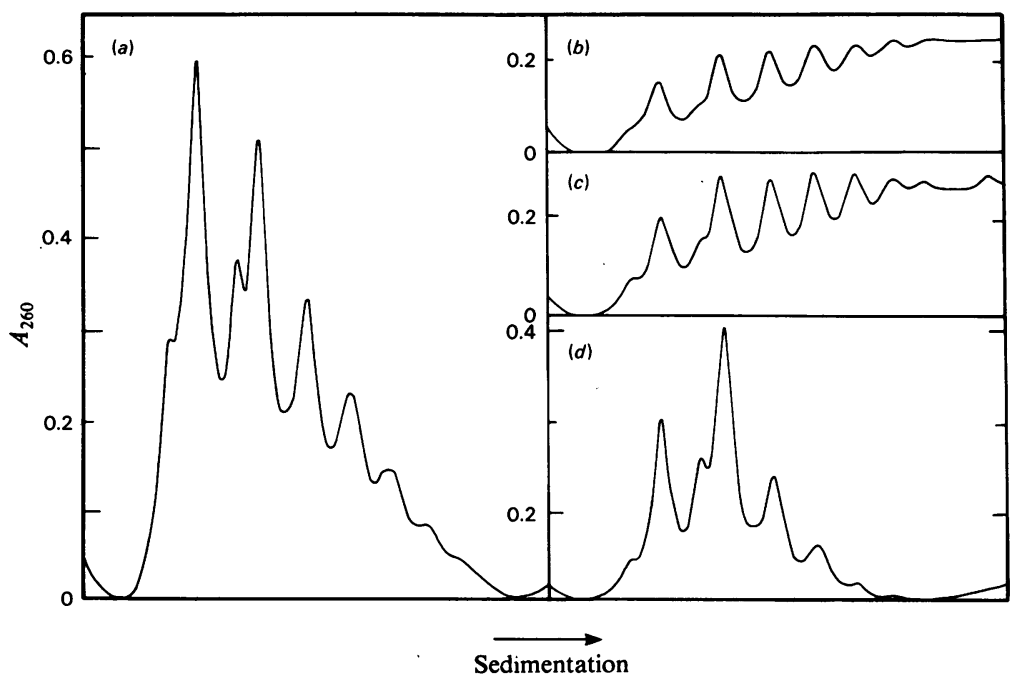

Fig. 1. Effect of oestradiol-17 $\beta$ on the sedimentation characteristics of uterine ribosomes

Groups of ten ovariectomized rats were killed at various times after injection of $10 \mu \mathrm{g}$ of oestradiol $17 \beta / 100 \mathrm{~g}$ body wt. The uteri were pooled and ribosomes prepared as described in the Materials and Methods section. The ribosomal preparations were analysed on $10-30 \%(w / v)$ sucrose gradients. The conditions for centrifugation were $38000 \mathrm{rev} . / \mathrm{min}$ in rotor SW 41 for $60 \mathrm{~min}$ at $4^{\circ} \mathrm{C}$ in the Beckman model L2-65B ultracentrifuge. Sedimentation was from left to right. (a) Control (unstimulated); (b) $24 \mathrm{~h}$ after stimulation; (c) $48 \mathrm{~h}$ after stimulation; (d) $72 \mathrm{~h}$ after stimulation. 


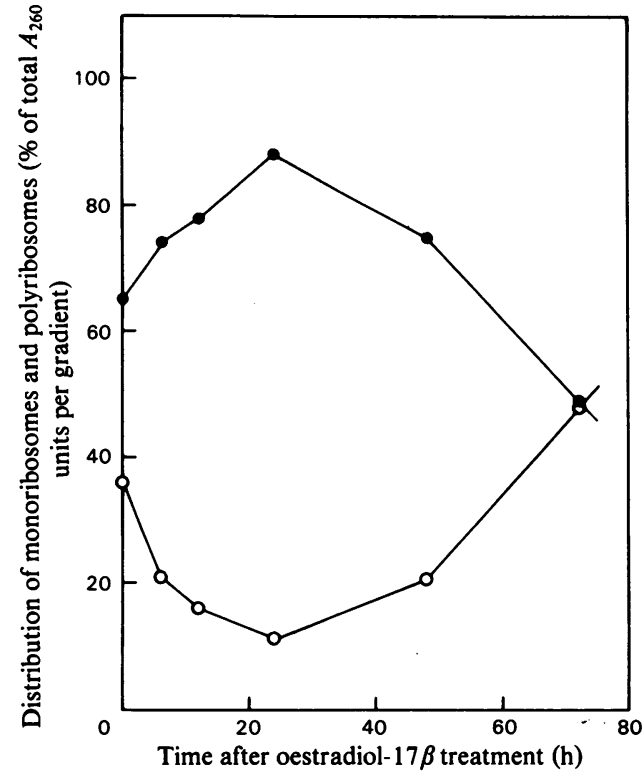

Fig. 2. Distribution of monoribosomes and polyribosomes as a function of time after stimulation

Ovariectomized rats received $10 \mu \mathrm{g}$ of oestradiol$17 \beta / 100 \mathrm{~g}$ body wt. at zero time and were killed at various times thereafter. Polyribosomes were isolated and analysed as described in the Materials and Methods section. The distribution of polyribosomes and monoribosomes in each gradient was determined by weighing the appropriate fractions of Xerox copies of the original printout of the gradient analyser. The results given are the mean values of at least ten experiments. @, Polyribosomes; $\mathrm{O}$, monoribosomes.

Table 1. Protein synthesis in oocytes from Xenopus laevis injected with polyribosomes from rat uteri The polyribosomes were obtained from animals $0,6,24$ and $60 \mathrm{~h}$ after hormone treatment. Into each oocyte was injected an amount of $176 \mathrm{ng}$ of polyribosomes in a total volume of $50 \mathrm{nl}$. For each time period a group of ten oocytes was used. The groups were incubated at $19^{\circ} \mathrm{C}$ for $15 \mathrm{~h}$, and the incorporation of $\left[{ }^{14} \mathrm{C}\right]$ leucine into polypeptides was determined as described in the Materials and Methods section. The endogenous activity of the oocytes was subtracted at each point.

Time after oestradiol-17 $\beta$

treatment
Incorporation of $\left[{ }^{14} \mathrm{C}\right]$ leucine into polypeptides Increase

$\begin{array}{cc}\text { (c.p.m./oocyte) } & \text { (\%) } \\ 7526 & - \\ 8773 & 17 \\ 18408 & 145 \\ 12202 & 62\end{array}$

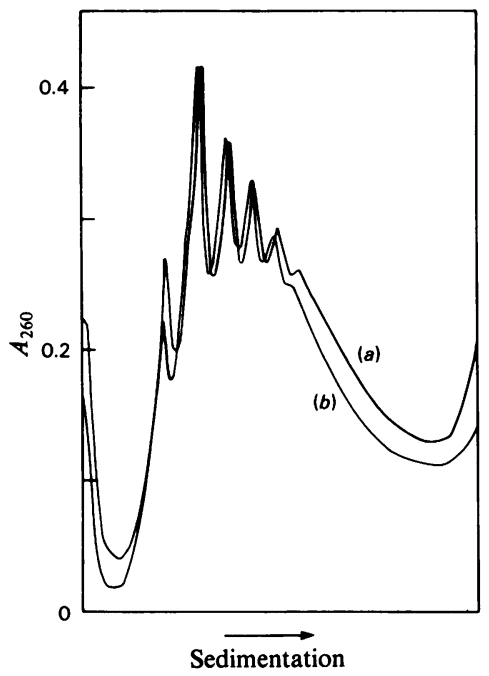

Fig. 3. Influence of a high-speed supernatant prepared from the uteri of control animals on the sedimentation profiles of polyribosomes from oestradiol-17ß-treated animals

A high-speed supernatant from the uteri of control animals was prepared by centrifugation of the homogenate in rotor 42.1 for $3 \mathrm{~h}$ at $40000 \mathrm{rev} . / \mathrm{min}$. Uteri were obtained from experimental animals $6 \mathrm{~h}$ after oestradiol-17 $\beta$ treatment. The uteri were divided into equal sections and the polyribosomes isolated in the presence $(a)$ or absence $(b)$ of the high-speed supernatant.

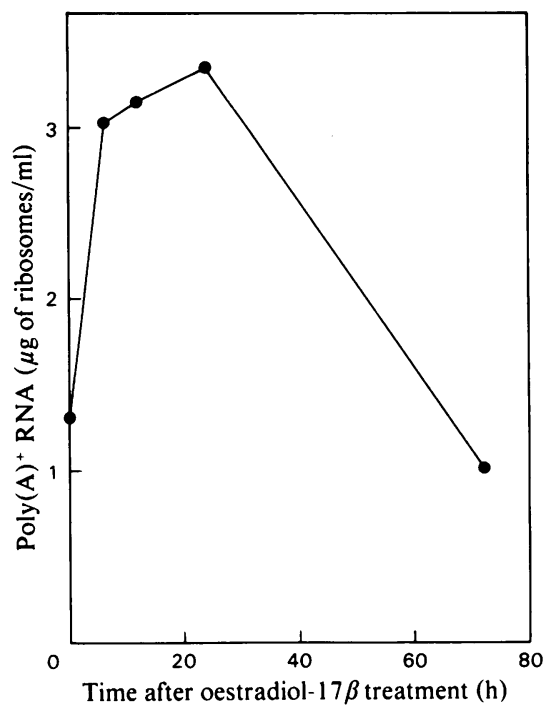

Fig. 4. Amount of polyribosomal poly $(A)^{+}$RNA recoverable by oligo(dT)-cellulose chromatography as a function of time after hormone administration

Poly(A) ${ }^{+}$RNA was isolated from uterine polyribosomes prepared from animals $0,6,12,24$ and $72 \mathrm{~h}$ after a single injection of oestradiol-17 $\beta$, as described in the Materials and Methods section. 
ribonuclease activity in the latter. It can therefore be concluded that the increase in the polyribosome/monoribosome ratio is likely to be a true reflection of the physiological effect of the hormone. The ability of these polyribosomes to stimulate protein synthesis was measured in oocytes of Xenopus laevis injected with the polyribosomes. It was observed (Table 1) that maximal incorporation of amino acids into polypeptides could be obtained with polyribosomes isolated from uteri of ovariectomized rats $24 \mathrm{~h}$ after oestradiol- $17 \beta$ treatment. This general pattern of amino acid incorporation was analogous to the pattern of polyribosomal changes (Fig. 2).

The relative amount of poly(A) ${ }^{+}$RNA present in

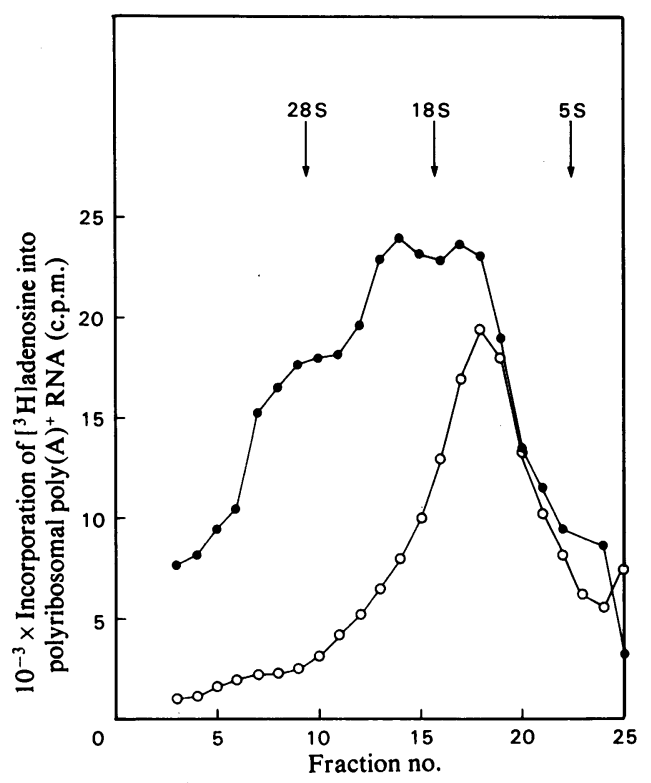

Fig. 5. Comparison of the effect of oestradiol-17 $\beta$ on the sedimentation characteristics of uterine polyribosomal poly $(A)^{+} R N A$ under different hormonal conditions Uterine polyribosomal poly(A) ${ }^{+}$RNA was isolated from control and experimental rats $15 \mathrm{~h}$ after hormone treatment. RNA obtained from equal amounts of ribosomes were subjected to oligo(dT)-cellulose chromatography. The poly(A) ${ }^{+}$ RNA-containing fractions were analysed on a linear $5-20 \%(w / v)$ sucrose density gradient by centrifugation for $6 \mathrm{~h}$ in rotor SW 41 at $38000 \mathrm{rev} . / \mathrm{min}$ at $4^{\circ} \mathrm{C}$ in the model L2-65B ultracentrifuge. The gradients were fractionated and the radioactivity was determined in each fraction as described. Total polyribosomal RNA was centrifuged in a separate gradient as markers. Sedimentation was from right to left. O, RNA from control animals; 0 , RNA from hormone-treated animals. polyribosomes at different times after hormonal stimulation was determined by fractionation of the total polyribosomal RNA on an oligo(dT)-cellulose column. The results in Fig. 4 show that the amount of poly(A)+ RNA recoverable from the ribosomal preparations increased with time after stimulation. This increase reached a maximum at $24 \mathrm{~h}$, after which it declined to a value less than that before stimulation.

A comparison between the poly(A) ${ }^{+}$RNA from control and hormone-treated animals was subsequently made by preparing poly(A) ${ }^{+}$RNA labelled in vitro by incubation of uterine tissue in the presence of $\left[2-{ }^{3} \mathrm{H}\right]$ adenosine. The RNA isolated from polyribosomes prepared from these uteri was fractionated on an oligo(dT)-cellulose column, and poly(A) ${ }^{+}$RNA fractions were analysed by sucrosedensity-gradient centrifugation (Fig. 5). The poly $(\mathrm{A})^{+}$RNA from the controls consisted of a heterogeneous population of RNA with a sedimentation value between $5 \mathrm{~S}$ and $25 \mathrm{~S}$. The hormone stimulation resulted in an increase in both the amount and the size (13S and 35S) of the RNA. The higher-molecular-weight RNA predominated in these RNA populations.

\section{Discussion}

The trophic response of the uterus of the ovariectomized rat to oestradiol-17 $\beta$ treatment includes increased synthesis of nuclear RNA and rRNA, mRNA accumulation and an increase in the rate of amino acid incorporation into polypeptides (Teng \& Hamilton, 1967; Hamilton et al., 1971). Teng \& Hamilton (1967) have furthermore observed that the profiles on sucrose density gradients of uterine polyribosomal preparations isolated from ovariectomized rats treated with hormone for 4,12 or $24 \mathrm{~h}$ were similar, suggesting that an overall change in size of polyribosomes did not occur during the period of hormone action examined. Our results (Figs. 1 and 2) show the contrary, but are in agreement with electron-microscopic analyses of changes in the ultrastructure morphology of uterine tissue in response to oestrogen treatment (Bo et al., 1968; Brökelman, 1977). Brökelman (1977) observed that a limited amount of polyribosomes were present in the epithelial cells of uteri from ovariectomized rats. In response to a single dose of oestradiol-17 $\beta$, the polyribosomes increased, reaching a maximal amount $24 \mathrm{~h}$ after treatment, whereafter the amount of polyribosomes diminished to values comparable with that in the untreated animal. We therefore conclude (1) that the changes in the polyribosomal profiles are a general characteristic of uterine cells in response to oestradiol-17 $\beta$ and not restricted to the epithelial cells only, and (2) that the changes in the polyribosomal profiles are a true 
reflection of the physiological changes in the uterine tissue in response to oestradiol-17 $\beta$.

The effect of oestradiol-17 $\beta$ on the uterine polyribosomes is apparently not limited to the adult rat, but can also be observed in the immature rat. In these animals the polyribosomal content changed from $59 \%$ in the controls to $93 \% 12 \mathrm{~h}$ after a single dose of oestradiol-17 $\beta$. This was accompanied by an increase in the overall protein-synthesizing activity by a factor of 2.3 (Gasde et al., 1971). J. T. Knowler (personal communication) has observed that the maximal increase in polyribosome formation in the immature rat occurred at 8-12 $\mathrm{h}$ after a single dose of oestradiol-17 $\beta$, and by 16 and $24 \mathrm{~h}$ the size and number of polyribosomes were decreasing. The increase in polyribosomes in response to a single administration of oestrogen to ovariectomized rats thus appears to be sustained much longer than in the immature animals. Another similarity of the hormone effect in the immature and the ovariectomized animal is a greater increase in the protein-synthesizing capacity in comparison with the increase in polyribosome/monoribosome ratio. In the ovariectomized rat the maximal increase in polyribosome content was $38 \% 24 \mathrm{~h}$ after hormonal stimulation (Fig. 2), which is less than the maximal increase in amino acid incorporation ( $145 \%$ after $24 \mathrm{~h}$; Table 1$)$. This increase in amino acid incorporation appears not to be dependent on the protein-synthesizing system used, since our results with oocytes of Xenopus laevis are in the same order of magnitude as those observed in a cell-free system using uterine ribosomes (Whelly \& Barker, 1974; Shapiro et al., 1975).

It has been shown (Catelli \& Baulieu, 1976) that oestradiol-17 $\beta$ does not stimulate early and exclusively the expression of a limited portion of the genome. Among the non-ribosomal RNA species, the total unfractionated cellular poly(A) ${ }^{+}$RNA fraction was the only one whose rate of synthesis continued to increase after the first hour of hormone stimulation. As indicated in Fig. 4, the amount of poly(A) ${ }^{+}$RNA recoverable from the polyribosomal fraction increased very rapidly within the first $6 \mathrm{~h}$ after stimulation, reaching a maximum at $24 \mathrm{~h}$. In the uteri of control animals the poly(A) ${ }^{+}$RNA furthermore consisted of a heterogeneous population of RNA with a sedimentation value between 5S and $25 \mathrm{~S}$, whereas those from hormone-treated rats increased in amount and size (13S to 35S). The higher-molecular-weight RNA predominated in the latter RNA populations (Fig. 5). From these results it is clear that the oestradiol-17 $\beta$ treatment induced qualitative and quantitative changes in the polyribosomal poly $(\mathrm{A})^{+}$RNA. The extent of these changes at the structural level remains to be established. In the immature rat the changes in complexity are apparently so profound that the poly(A) ${ }^{+}$RNA from the uteri of unstimulated immature rats has so little in common with that $4 \mathrm{~h}$ after oestradiol-17 $\beta$ administration to the rats that there can be very little complementarity between the two (Aziz et al., 1979).

We thank Professor W. Fitschen for reading the manuscript and making helpful suggestions. The work was supported by grants from the South African Medical Research Council and the South African Atomic Energy Board.

\section{References}

Aziz, S. \& Knowler, J. T. (1978) Biochem. J. 172, 587-593

Aziz, S., Balmain, A. \& Knowler, J. T. (1979) Eur. J. Biochem. 100, 95-100

Bo, W. J., Oder, D. L. \& Rothrock, M. (1968) Am. J. Anat. 123, 369-384

Brökelman, J. (1977) Cell Tissue Res. 179, 517-530

Busch, H. (1976) Methods Cancer Res. 13, 101-197

Catelli, M. G. \& Baulieu, E.-E. (1976) Mol. Cell. Endocrinol. 6, 129-151

Chan, L., Kohler, P. O. \& O’Malley, B. W. (1976) J. Clin. Invest. 57, 576-585

Eilon, G. \& Gorski, J. (1972) Fed. Proc. Fed. Am. Soc. Exp. Biol. 31, 245 (abstr. 189)

Gasde, K., Kramer, G. \& Schultz, K.-D. (1971) HoppeSeyler's Z. Physiol. Chem. 352, 318-320

Gurdon, J. B., Lane, C. D., Woodland, H. R. \& Marbaix, G. (1971) Nature (London) 233, 177-182

Hamilton, T. H., Teng, C.-C., Means, A. R. \& Luck, D. N. (1971) in The Sex Steroids: Molecular Mechanisms (McKerns, K. W., ed.), pp. 197-243, AppletonCentury-Crofts, New York

Katzenellenbogen, B. \& Gorski, J. (1975) Biochem. Actions Horm. 3, 187-243

Krystosek, A., Cawthon, M. L. \& Kabat, D. (1975) J. Biol. Chem. 250, 6077-6084

Luck, D. N. (1979) in Ontogeny of Receptors and Reproductive Horinone Action (Hamilton, T. H., Clark, J. H. \& Sadler, W. A., eds.), pp. 133-148, Raven Press, New York

Manchester, K. L. (1974) Biochemistry 13, 3062-3068

Pretorius, P. J. \& Reinecke, C. J. (1979) Abstr. Int. Congr. Biochem. 11th, 11-6-S3

Reader, R. W. \& Stanners, C. P. (1967) J. Mol. Biol. 28, 211-223

Shapiro, S. S., Phiromsawat, S. \& Hagerman, D. P. (1975) Biochem. Biophys. Res. Commun. 62, 376-381

Suvatte, A. B. \& Hagerman, D. D. (1970) Endocrinology 87, 641-645

Teng, C.-C. \& Hamilton, T. H. (1967) Biochem. J. 105, 1101-1109

Whelly, S. M. \& Barker, K. L. (1974) Biochemistry 13, 341-346 